
A C T A

\title{
ACTIVATION AND MOTILITY OF SPERMATOZOA OF VENDANCE (COREGONUS ALBULA L.)
}

\section{AKTYW ACJA I RUCHLIWOŚĆ PLEMNIKÓW SIELAWY (COREGONUS ALBULA L.)}

\author{
Department of Anatomy and Embryology of Fish, \\ University of Agriculture, Szczecin
}

\begin{abstract}
The number of activated spermatozoa of vendance (Coregonus albula L.) and their motility under natural conditions at the fishing ground were determined. The percentage of spermatozoa activated upon contact with water was foud to be relatively high, and motility period (turbulent and smooth phase of progressive movement, and oscillatory movement) - fairy long, i.e. exceeding $2 \mathrm{~min}$.
\end{abstract}

\section{INTRODUCTION}

Vendance spermatozoa, as well as their behaviour after contact with water, i.e. the course of activation and - consequently - of motility, have not so far been extensively studied, perhaps because this species is "exacting" with respect to the environmental conditions and occurs in masses only in lakes with high water quality parameters (as a rule oligotrophic lakes of the so-called vendance-type, or deep lakes with pure bottom). For this reason, in the case of vendance, as compared with other fish species, less attention has been given to its artificial reproduction and to attempts at its acclimation to other water bodies, this being always associated with obtainment of sexual products, their storage, transport etc.

On the other hand, breeding treatments involving artificial hatching of vendance, widely applied since many decades, rely on practical experience of fisheries and are 
aimed only at supporting the local populations or at supplementing the fish stocks living in reservoirs undergoing gradual degradation. On acount of intensification on this degradation, the interest of scientists in artificial hatching of vendance, and thus in the possible physiological specificity of its sexual cells, may gradually gain in intensity.

The present study deals with the activation and motility of vendance spermatozoa obtained from living males at the fishing ground.

\section{MATERIAL AND METHODS}

Sperm was derived from living fish selected at random at the fishing ground (Krzemień Lake, commune of Sieraków) in November 1991.

Males taken out from water were dried with a linen towel. By gentle massaging of the ventral side from head to tail, sperm was expressed on watch glasses. A sperm droplet (ca. $0.02 \mathrm{~mm}^{3}$ ) was placed on an object glass using a sharpened wooden rod, and was covered with a water drop suspenseded on a cover glass. The moment of contact of the sperm droplet with water was accepted as the starting point from which time was measured (in sec).

The motility time of spermatozoa was calculated by separately measuring the time of the progressive movement (turbulent and smooth phase) and oscillatory movement (when the spermatozoa do not move onward and only perform lateral movements with a frequency decreasing over time).

Moreover, the relative number of the nonactivated spermatozoa, i.e. of those remaining completely immobile, was determined. It is stressed that whereas the data obtained by microscopic inspection are charged with some error, measuring of the progressive and oscillatory movement time in triplicate afforded fairly objective results closely approaching the real ones.

All observation and counts were performed at an improvised laboratory situated near a fishig station, at ambient temperature of $4.5^{\circ} \mathrm{C}$. The temperature of lake water used for activating the permatozoa was also $4.5^{\circ} \mathrm{C}$.

Observations were taken under on optical microscope at magn. $200 \mathrm{x}$.

As above mentioned, for each male all measurements and counts were performed in triplicate, and the mean values were calculated. Confidence intervals for the means were obtained by analysis of variance.

\section{RESULTS}

The average values of all investigated indices (\% of the spermatozoa activated upon contact with water, time of movement during the different phases, and cumulative 
Activation and motility duration of the spermatozoa of vendance,

Coregonus albula L. (temp. $4.5^{\circ} \mathrm{C}$ )

\begin{tabular}{|c|c|c|c|c|c|c|}
\hline \multirow{2}{*}{ Lp. } & \multirow{2}{*}{$\begin{array}{c}\text { No. of } \\
\text { activated } \\
\text { supermatozoa } \\
(\%)\end{array}$} & \multicolumn{3}{|c|}{$\begin{array}{l}\text { Period of progressive movement } \\
\text { (S) }\end{array}$} & \multirow{2}{*}{$\begin{array}{c}\text { Period } \\
\text { of } \\
\text { oscillatory } \\
\text { movement (s) }\end{array}$} & \multirow{2}{*}{$\begin{array}{c}\text { Total } \\
\text { motility } \\
\text { duration } \\
(\mathrm{s})\end{array}$} \\
\hline & & $\begin{array}{c}\text { turbulent } \\
\text { phase }\end{array}$ & $\begin{array}{l}\text { smooth } \\
\text { phase }\end{array}$ & $\begin{array}{l}\text { total time } \\
\text { of motility }\end{array}$ & & \\
\hline 1 & 75 & 32 & 29 & 61 & 101 & 162 (2'42') \\
\hline 2 & 62 & 30 & 35 & 65 & 95 & $160\left(2^{\prime} 40^{\prime \prime}\right)$ \\
\hline 3 & 80 & 34 & 40 & 74 & 63 & 137 (2'17’') \\
\hline 4 & 98 & 33 & 41 & 74 & 45 & 119 (1'59’') \\
\hline 5 & 93 & 31 & 37 & 68 & 59 & 127 (2’07’') \\
\hline 6 & 80 & 33 & 39 & 72 & 53 & 125 (2’05’) \\
\hline 7 & 45 & 22 & 39 & 61 & 50 & 111 (1'51”) \\
\hline 8 & 82 & 28 & 32 & 60 & 60 & 120 (2’00’') \\
\hline 9 & 97 & 35 & 36 & 71 & 66 & 137 (2'17') \\
\hline 10 & 100 & 38 & 32 & 70 & 87 & 157 (2’37’’) \\
\hline 11 & 97 & 39 & 29 & 68 & 47 & 115 (1'55”) \\
\hline $\begin{array}{l}95 \% \\
\text { int }\end{array}$ & $\begin{array}{l}\bar{x} \pm \text { S.E. } \\
\% \text { confidence } \\
\text { ervals for means }\end{array}$ & $30.9-33.5$ & $33.5-37.0$ & $65.3-69.7$ & $66.0 \pm 3.3$ & $\begin{array}{l}133.5 \pm 3.0 \\
127.2-139.7\end{array}$ \\
\hline
\end{tabular}

results) are recorded in Table 1. The results indicate that despite the particular cautionsness and gentleness in sperm expression from gonads, in virtually all samplesof sperm obtained from males at the fishing ground not all spermatozoa became activated upon contact with water (with the exception of one male). The overall mean percentage of activated spermatozoa was over $80 \%$, with a dispersion range of $45-100 \%$.

The mean time of spermatozoa motility after activation slightly exceeded $2 \mathrm{~min}$; The progressive and oscillatory movement phases accounted for $50.4 \%$ and $49.6 \%$, respectively, of this time. The constancy of the values of these indices is noteworthy. 


\section{DISCUSSION AND CONCLUSIONS}

The presents results indicate that the behaviour of vendance spermatozoa after contact with water, considered from the angle of their motility, does not particularly depart from that reported for other freshwater fish [Lindroth, 1947; Bertin, 1958; Opuszyński, 1979; Scott and Baynes, 1980], in which the considerable difference in osmotic pressure between the protoplasm of the spermatozoon head and the environment results in realtively rapid water absorption inwards the spermatozoa [Beljaev, 1957; Winnicki and Tomasik, 1976; Billard, 1978; Tomasik and Sobociński, 1979; Tomasik and Winnicki, 1987]; for this reason in freshwater fish, compared with marine fish, the time of spermatozoa motility is shorter.

It is noteworthy that the time of progressive movement of the spermatozoa, found in the present studies, amounted to ca. $1 \mathrm{~min}$ and even more, i.e. it was by nearly one half longer, as compared with the findings of other authors. This seems to be due to the effect of temperature which in the present experiments was $4.0-4.5^{\circ} \mathrm{C}$ whereas in most other studies it amounted to $10^{\circ} \mathrm{C}$ or more. Also the prolonged time of oscillatory movement (up to ca. $1 \mathrm{~min}$ ) and protracted cumulative time of motility (progressive and oscillatory movement) more than 2 min can be explained in terms of the effect of temperature.

In the present studies, in the course of the progressive movement we singled out two phases: turbulent and smooth [Nomura, 1964; Yoshida and Nomura, 1972; Tomasik, 1973; Formicki et al., 1989]; their duration was more or less equal. Thus, when the total period of spermatozoa motility is considered, ca. $25 \%$, of its duration fall to the turbulent phase of the progressive movement, $25 \%$ - to the smooth phase of this movement, and ca. $50 \%$ - to the oscillatory movement. The time of the oscillatory movement, expressed in relative numbers, is much longer than the respective values by Tomasik [1973] for the spermatozoa of other salmonids.

The index of the number of spermatozoa activated after contact with water, found in the present experiments, is in general high and sometimes very differentiated. Whereas this phenomenon has been widely observed, only few authors called attention to it.

Not all spermatozoa present in sperm become activated upon contact with water. This seems to be due to the fact that during expression of sperm from small males it is only rarely possible to avoid too strong a pressure on the gonads; consequently, together with sperm filling the seminal canals, also the spermatozoa occuring in the testicular cavernae are expressed via the cloaca. These spermatozoa seem to be structurally mature, though not yet physiologically prepared for motility. They are a sui generis reserve for the observed manifold ejaculates produced a number of times during hatching by the male cooperating with several females. 
These consideration confirm the observatioris by Tomasik and Sobociński [1987] and the results concerning the spermatocrit [Winnicki and Tomasik, 1976; Tomasik and Winnicki, 1987], according to which the spermatocrit fluctuates within a wide range; this is also reflected by great differentiation of the ejaculate consistency.

\section{REFERENCES}

Beljaer E.V., 1957: Nekotoryje osobennosti fizjologii spermy i jaic ryb. - Trudy Mosk. Techn. In-ta Rybn. Promyšl. i Ch-va, 8: 271-277. (in Russian).

Bertin L., 1958: Sexualité et Fecondation. - in: Traité de Zoologie, 13 (2): 1584-1652.

Billard R., 1978: Changes in structure and fertilizing ability of marine and freshwater fish spermatozoa diluted in media of various salinities. - Aquaculture, 14: 187-198.

Formicki K., M. Kowalewski, A. Sobociniski, L. Tomasik, A. Winnicki, 1989: Motility of Danube salmon (Hucho hucho L.) spermatozoa after activation. - Acta Ichth. Pisc., 19, 2: 29-35.

Lindroth A., 1947: Time of activity of freshwater fish spermatozoa in relation to temperature. - Zool. Biol. Uppsala, Festskrift, 25: 165-168.

Nomura M., 1964: Studies on reproduction of rainbow trout Salmo gairdneri, with special reference to egg taking. VI. The activities of spermatozoa in different diluents, and preservation of semen. - Bull. Jap. Soc. Sci. Fish., 30: 723-733.

Opuszyniski K., 1979: Podstawy biologii ryb. [Biology of fish]. PWRiL, Warszawa. (in Polish).

Scott A.P., S.M. Baynes, 1980: A review of the biology, handling and storage of salmorid spermatozoa. J. Fish Biol., 17: 707-739.

Tomasik L., 1973: Specific and individual differences in motility between salmonid spermatozoa. - Acta Ichth. Pisc., 3, 1:11-17.

Tomasik L., A. Sobociñski, 1979: Effect of salinity on motility and viability of salmonid spermatozoa. Acta Ichth. Pisc., 9, 2: 3-14.

Tomasik L., A. Sobocinsski, 1987: Quality of rainbow trout (Salmo gairdneri Rich.) spermatozoa collected from different sections of the vas defferens. - Acta Ichth. Pisc., 17, 2: 49-54.

Tomasik L., A. Winnicki, 1987: Wpływ uwodnienia plemnika ryby na jego aktywnošć ruchową i zdolnošć do zapłodnienia. - Streszczenia referatów na XIV Zjazd PTZool w Szczecinie. 17-19 września 1987. [Influence of water uptake of fish spermatozoa on its motility and ability for fertilization]. Wyd. Akademii Rolniczej w Szczecinie, Szczecin: 214. (in Polish).

Winnicki A., L. Tomasik, 1976: "Spermatocrit" as a method for biological evaluation of fish sperm. - Acta Ichth. Pisc., 6, 2:3-8.

Yoshida T., M. Nomura, 1972: A substance enhancing sperm motility in the ovarian fluid of rainbow trout. - Bull. Jap. Soc. Sci. Fish., 38: 1073. 
Aleksander WINNICKI, Krzysztof FORMICKI

\section{AKTYWACJA I RUCHLIWOŚĆ PLEMNIKÓW SIELAWY \\ (COREGONUS ALBULA L.)}

\section{STRESZCZENIE}

Badano ilości aktywujących się plemników sielawy (Coregonus albula L.) oraz ich ruchliwość w warunkach naturalnych na łowisku. Stwierdzono relatywnie wysoki odsetek plemników aktywujących się po zetknięciu $z$ wodą oraz względnie długi, bo przekraczający 2 minuty okres aktywności ruchowej (faza burzliwa i spokojna ruchu postępowego oraz ruch wahadłowy).

Author's address:

Prof. dr hab. Aleksander Winnicki, prof. dr hab. Krzysztof Formicki

Zakład Anatomii i Embriologii Ryb

Akademia Rolnicza

ul. K. Krölewicza 4

71-550 Szczecin

Polska (Poland) 